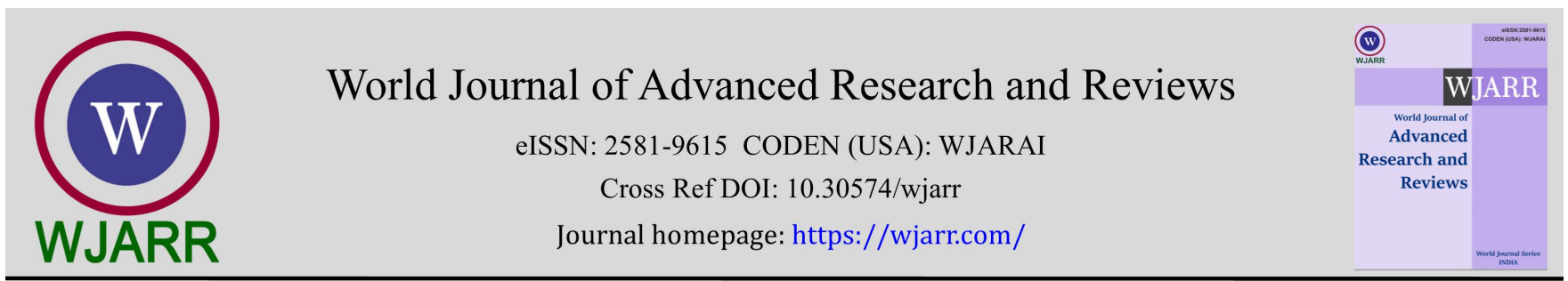

(RESEARCH ARTiClE)

Check for updates

\title{
Agro-morphological characterization of beans of the phaseolus genus and identification of their cultivated species in Benin (West Africa)
}

\author{
Houssou Wilfried Milognon 1, 2, *, Antoine Abel Missihoun 1, 2, Jonas Boco ${ }^{3}$, Achille Ephrem Assogbadjo ${ }^{4}$ and \\ Clement Agbangla 1,2 \\ ${ }^{1}$ Laboratory of Molecular Genetics and Genomes Analysis, Faculty of Sciences and Technics, University of Abomey-Calavi, \\ 01 PO Box: 526, Cotonou, Benin. \\ 2 Laboratory of Genetics and Biotechnologies, Faculty of Sciences and Technics, University of Abomey-Calavi, 01 PO Box: \\ 526, Cotonou, Benin. \\ 3 Innovative Hub for Research in Africa (IHfRA), 2409 PO Box: 762 Ouagadougou 09, Burkina Faso. \\ ${ }^{4}$ Laboratory of Applied Ecology, Faculty of Agronomic Sciences, University of Abomey-Calavi, 05 PO Box: 1752, Cotonou, \\ Benin.
}

World Journal of Advanced Research and Reviews, 2022, 13(02), 331-345

Publication history: Received on 01 December 2021; revised on 10 February 2022; accepted on 12 February 2022

Article DOI: https://doi.org/10.30574/wjarr.2022.13.2.0669

\begin{abstract}
The local cultivars of the Phaseolus genus present within the local communities constitute a considerable source of genes and consequently of genetic diversity which would lead to success of the varietal creation of beans. Nevertheless, these resources suffer from a significant genetic erosion because of the climatic requirement but also of the difficulties related to their cultivation methods. The objective of this study is to identify the phenotypical distinctive features of the species of the Phaseolus genus cultivated in Benin for a permanent management. To achieve this goal, an agro-morphological characterization was carried out on two years (2019-2020) from March to August of each, at Ahossougbéta (AbomeyCalavi) following a completely randomized blocks design with three replications. Data were collected on twenty-three measured characters on 88 accessions. Data were subjected to the descriptive analysis, the analysis of variance and the multivariate analyses. Results showed a great variability among the accessions for the studied cultivars. Three major groups were identified and were characterized by the AFD. The studied cultivars were characterized more by the shape of the first leaves, the color of the flowers, the color of the integuments, the width of the pods, times of flowering and appearance of the pods and the width and the length of the pods. These results are significantly important for the classification of beans species of the Phaseolus genus. In addition, morphological and molecular genetic characterizations are necessary within each specie in order to define strategies for the improvement and the conservation of their genetic resources in Benin.
\end{abstract}

Keywords: Phaseolus spp; Hierarchical Ascendant Classification (CAH); Discriminant Factorial Analysis (AFD); Abomey-Calavi; Benin

\section{Introduction}

Food and nutritional security are major priority in the whole world and mainly in the developing countries. Nowadays, food and nutritional demand is mainly assured by resources of vegetable origin because they are easily accessible to the populations [1]. The beans of the Phaseolus genus are vegetable resources which appear in good place among food legumes in the world. The Phaseolus genus gathers approximately about sixty species belonging all to the family of

\footnotetext{
${ }^{*}$ Corresponding author: Houssou Wilfried Milognon; E-mail: frignhone@gmail.com

Laboratory of Molecular Genetics and Genomes Analysis, Faculty of Sciences and Technics, University of Abomey-Calavi, 01 PO Box: 526, Cotonou, Benin.

Copyright $(2022$ Author(s) retain the copyright of this article. This article is published under the terms of the Creative Commons Attribution Liscense 4.0.
} 
Fabaceae [2]. They are annual plants, herbaceous long-lived, seldom woody, with stems short or generally hails and lengthened, climbing and voluble on the right, i.e. rolled up of left on the right, while going up on a tutor $[3,4,5]$. Belonging to under tribe of Phaseoleae, the tribe of Phaseolineae and the order of Fabales, the beans of the Phaseolus genus have their center of origin in Central and the Southern America. This genus contains species whose morphological characteristics are very similar but with some differences observed on the morphological features among species [4,6]. Species of great importance, the potential benefits of Phaseolus beans are numerous and for a long time illustrated by results of the studies on animal models [7], the schift and the rotation of crops [8, 9] but also of the studies of intervention from man [10]. Indeed, several studies showed that the consumption of beans is recommended to the people suffering from obesity and having disorders of the nervous system, rheumatisms, of gastro-enteritis or in poultice $[10,11,12]$. They also constitute a significant source of starch (starchy food) with weak index glycaemic [13], cheap sources of proteins [14], and micronutrients such as Iron, Magnesium, Calcium and Zinc, but also of fibres for more than 300 million people in the Tropics $[13,14]$. The small African farmers cultivate each year in family agriculture more than four million hectares of beans with approximately $85 \%$ of the production used for home consumption [15] constituting a source of food for more than 100 million Africans[16]. Because beans offer a profile in amino acids opposed to that of cereals i.e., that they contain the essential amino acids (32\% of the full amino acids) with a strong proportion out of lysine but whose sulphur amino acids (methionine and cysteine) constitute the limiting factors but found in sufficient quantity at cereals, the roots and tubers, etc. $[18,19,20]$; several authors agree that the simultaneous consumption of these food products constitutes a complement to correct the deficit in essential amino acids not only for the vegetarians but more particularly in the most stripped households which have difficult access to animal protein because of its high cost for this social class [5, 21, 22, 23, 24]. Also, in the crops production, the beans just like any other legume plants, nodosities which they carry on their roots or sometimes on their stems containing symbiotic bacteria rhizobia, are regarded as excellent converters of atmospheric mineral easily assimilable ammonia nitrogen by the plants $[9,25]$. Therefore, the beans hold a place of choice in agriculture, contributing largely to nutritional and food security and thus with the well-being of many civilizations in the world [26]. These numerous nutritional advantages that the beans offer, attracted for a decade, the attention of the Congolese authorities who selected these speculations among the strategic cultures within the framework of the National Program of Food Safety to solve the problems of malnutrition in RDC [27]. In Benin, the management of these cultures of great importance is still a business of the local populations because the majority of the institutions of search and agricultural services for advisory service of Benin focused mainly their research on the cereal, roots and tubers and cash crops, with little attention on legumes [28, 29] whereas these crops could serve as alternative for mitigating climatic change effects and edaphic constraints in agriculture. Therefore, It become urgent to use the morphological features for the clarification of the various species and local varieties cultivated in Benin with an aim to popularize them in our natural ecosystems and evaluate their molecular genetic diversity for finally projecting relevant programmes of improvement on these cultures. The objective of this study is to evaluate the genetic diversity among the Phaseolus genus. Specifically, this study aimed to identify the distinctive phenotypical features of the species of the Phaseolus genus cultivated in Benin.

\section{Material and methods}

\subsection{Vegetable material}

The evaluation of Agro morphological diversity related to a collection of 99 accessions of beans exploited by the populations of Benin of which 88 arrived in the long term. The origin of these accessions, their local names as their codes are consigned in the table 1.

\subsection{Description of the site}

The study was conducted on an experimental site at Ahossougbéta (district of Togba) in the Commune of AbomeyCalavi, Department of Atlantic (Figure 1). This zone is located between $7^{\circ} 30^{\prime}-9^{\circ} 45^{\prime} \mathrm{N}$ and $002^{\circ} 04-002^{\circ} 11$ of the subequatorial zone. The study location is characterized by a sandy and ferralitic soils. The climate is bimodal with two rainy seasons from March to July and from September to November and two dry seasons from August to September and December to February. The Annual pluviometry varies between 800 to $1200 \mathrm{~mm}$ in the West and 1000 to $1400 \mathrm{~mm}$ in the East. The relative humidity varied between $69 \%$ and $97 \%$ and the annual temperature oscillates between 25 and $29^{\circ} \mathrm{C}[30,31]$. 
Table 1 Origins and local names of varieties

\begin{tabular}{|c|c|c|c|c|c|c|c|}
\hline $\mathbf{N}^{\circ}$ & Codes & Local names & Origins & $\mathbf{N}^{\circ}$ & Codes & Local names & Origins \\
\hline 1 & KpDCn1 & Eglin-jin (noir) & $\begin{array}{l}\text { Djakotomey/ } \\
\text { Kpayahoué }\end{array}$ & 45 & SSCn1 & Djiyikun wiwi & $\begin{array}{l}\text { Savalou/ } \\
\text { Sohèdji }\end{array}$ \\
\hline 2 & ATDn3 & Koudrokou & $\begin{array}{l}\text { Toviklin/ } \\
\text { Adjido }\end{array}$ & 46 & SSCn3 & $\begin{array}{l}\text { Kpahunkpalaki } \\
\text { daninho } \\
\text { (danindji) }\end{array}$ & $\begin{array}{l}\text { Savalou/ } \\
\text { Sohèdji }\end{array}$ \\
\hline 3 & KpDCn6 & $\begin{array}{l}\text { Kpahunkundjo } \\
\text { wansanwansan }\end{array}$ & $\begin{array}{l}\text { Djakotomey/ } \\
\text { Kpayahoué }\end{array}$ & 47 & $\operatorname{SSCn} 2$ & Djiyikun vovo & $\begin{array}{l}\text { Savalou/ } \\
\text { Sohèdji }\end{array}$ \\
\hline 4 & HDDCn4 & $\begin{array}{l}\text { Kpahunkundjo } \\
\text { wansanwansan }\end{array}$ & $\begin{array}{l}\text { Djakotomey/ } \\
\text { Houégamey }\end{array}$ & 48 & $\operatorname{SSCn} 4$ & $\begin{array}{l}\text { Kpahunto } \\
\text { bodèho } \\
\text { (bodedji) }\end{array}$ & $\begin{array}{l}\text { Savalou/ } \\
\text { Sohèdji }\end{array}$ \\
\hline 5 & SDCn5 & Ayukpahunkun & $\begin{array}{l}\text { Djakotomey/ } \\
\text { Sègbèhoué }\end{array}$ & 49 & AOGn1 & $\begin{array}{l}\text { Akpakun } \\
\text { wéwé }\end{array}$ & Ouèssè/Gbémè \\
\hline 6 & ATDn5 & Koudrokoudjo & $\begin{array}{l}\text { Toviklin/ } \\
\text { Dékandji }\end{array}$ & 50 & SBZn1 & $\begin{array}{l}\text { Akpakun } \\
\text { wlanwlan }\end{array}$ & $\begin{array}{l}\text { Bohicon/ } \\
\text { Sodohomè }\end{array}$ \\
\hline 7 & $\mathrm{KpDCn} 2$ & Eglin-jin (rouge) & $\begin{array}{l}\text { Djakotomey/ } \\
\text { Kpayahoué }\end{array}$ & 51 & GOLn4 & $\begin{array}{l}\text { Akpakun } \\
\text { wéwé } \\
\text { winninwinnin }\end{array}$ & $\begin{array}{l}\text { Glazoué/ } \\
\text { Yagbo }\end{array}$ \\
\hline 8 & KDCn1 & Eglin-jin (noir) & $\begin{array}{l}\text { Djakotomey/ } \\
\text { Kokohoué }\end{array}$ & 52 & AAZn1 & $\begin{array}{l}\text { Akpakun } \\
\text { wéwé }\end{array}$ & $\begin{array}{l}\text { Agbangnizoun } \\
\text { /Gnizita }\end{array}$ \\
\hline 9 & $\operatorname{SDCn} 3$ & $\begin{array}{l}\text { Koudrokou } \\
\text { wansanwansan }\end{array}$ & $\begin{array}{l}\text { Djakotomey/ } \\
\text { Sègbèhoué }\end{array}$ & 53 & PBZn1 & $\begin{array}{l}\text { Akpakun } \\
\text { wlanwlan } \\
\text { vovo }\end{array}$ & $\begin{array}{l}\text { Bohicon/ } \\
\text { Djohounta }\end{array}$ \\
\hline 10 & HDDCn1 & Koudrokou & $\begin{array}{l}\text { Djakotomey/ } \\
\text { Houégamey }\end{array}$ & 54 & LBZn2 & $\begin{array}{l}\text { Akpakun } \\
\text { wlanwlan }\end{array}$ & $\begin{array}{l}\text { Bohicon/ } \\
\text { Lissèzoun }\end{array}$ \\
\hline 11 & $\operatorname{DDCn} 2$ & Gbodokpahunkun & $\begin{array}{l}\text { Djakotomey/ } \\
\text { Dahouèhoué }\end{array}$ & 55 & HZZZn3 & $\begin{array}{l}\text { Akpakun } \\
\text { wéwé }\end{array}$ & $\begin{array}{l}\text { Zogbodomey/ } \\
\text { Hlagba-Zakpo }\end{array}$ \\
\hline 12 & KDCn4 & Koudrokoudjo & $\begin{array}{l}\text { Djakotomey/ } \\
\text { Kokohoué }\end{array}$ & 56 & $\begin{array}{l}\text { MaGCn } \\
1\end{array}$ & Lègbakpakun & Glazoué \\
\hline 13 & $\operatorname{SDCn} 1$ & Kpahunkunjo & $\begin{array}{l}\text { Djakotomey/ } \\
\text { Sègbèhoué }\end{array}$ & 57 & SGCn1 & $\begin{array}{l}\text { Kpamlakun } \\
\text { kpikpa }\end{array}$ & Glazoué/Sowé \\
\hline 14 & ATDn4 & Kpahunkunjo & $\begin{array}{l}\text { Toviklin/ } \\
\text { Dékandji }\end{array}$ & 58 & SGCn2 & $\begin{array}{l}\text { Kpamlakun } \\
\text { founfoun }\end{array}$ & Glazoué/Sowé \\
\hline 15 & $\mathrm{KDCn} 2$ & Kpahunkun yi & $\begin{array}{l}\text { Djakotomey/ } \\
\text { Kokohoué }\end{array}$ & 59 & GOLn & Séssé & $\begin{array}{l}\text { Glazoué/ } \\
\text { Lifodji }\end{array}$ \\
\hline 16 & HDDCn3 & Kpahunkundjo & $\begin{array}{l}\text { Djakotomey/ } \\
\text { Damagahoué }\end{array}$ & 60 & $\operatorname{SDCn} 2$ & $\begin{array}{l}\text { Gbodo } \\
\text { kpahunkunyi }\end{array}$ & Sègbèhoué \\
\hline 17 & KDCn6 & Eglin-jin (noir) & $\begin{array}{l}\text { Djakotomey/ } \\
\text { Kokohoué }\end{array}$ & 61 & ZOGn3 & Séssé & $\begin{array}{l}\text { Glazoué/ } \\
\text { Zoungoundo }\end{array}$ \\
\hline 18 & KpDCn4 & Koudrokou & $\begin{array}{l}\text { Djakotomey/ } \\
\text { Kpayahoué }\end{array}$ & 62 & ZZZn1 & $\begin{array}{l}\text { Akpakun } \\
\text { wéwé }\end{array}$ & Zogbodomey \\
\hline 19 & HDDCn 6 & $\begin{array}{l}\text { Kpahunkundjo } \\
\text { wansanwansan }\end{array}$ & $\begin{array}{l}\text { Djakotomey/ } \\
\text { Gohomey }\end{array}$ & 63 & GACn1 & $\begin{array}{l}\text { Akpakunvovo } \\
\text { dogoué- } \\
\text { dogoué }\end{array}$ & $\begin{array}{l}\text { Glazoué/ } \\
\text { Assanté }\end{array}$ \\
\hline 20 & ATDn1 & $\begin{array}{l}\text { Kpahunkundjo } \\
\text { wansanwansan }\end{array}$ & Toviklin/ Lalo & 64 & MSCn3 & $\begin{array}{l}\text { Akpakun } \\
\text { sanwansanwan }\end{array}$ & $\begin{array}{l}\text { Savalou/ } \\
\text { Monkpa }\end{array}$ \\
\hline
\end{tabular}


World Journal of Advanced Research and Reviews, 2022, 13(02), 331-345

\begin{tabular}{|c|c|c|c|c|c|c|c|}
\hline 21 & DDCn1 & Koudrokoudjo & $\begin{array}{l}\text { Djakotomey/ } \\
\text { Dahouèhoué }\end{array}$ & 65 & HZZZn2 & $\begin{array}{l}\text { Akpakun } \\
\text { wéwé }\end{array}$ & Hlagba-Zakpo \\
\hline 22 & ATDn2 & $\begin{array}{l}\text { Koudrokou } \\
\text { wansanwansan }\end{array}$ & Toviklin/ Lalo & 66 & FOGn1 & Dansi kpika & $\begin{array}{l}\text { Glazoué/ } \\
\text { Finangnon }\end{array}$ \\
\hline 23 & DDCn3 & Kpahunkundjo & $\begin{array}{l}\text { Djakotomey/ } \\
\text { Dahouèhoué }\end{array}$ & 67 & AAZn2 & $\begin{array}{l}\text { Akpakun } \\
\text { wéwé }\end{array}$ & $\begin{array}{l}\text { Agbangnizoun } \\
\text { /Adanhondjigon }\end{array}$ \\
\hline 24 & MSCn2 & Akpakun vovo & $\begin{array}{l}\text { Savalou/ } \\
\text { Monkpa }\end{array}$ & 68 & DBZn1 & $\begin{array}{l}\text { Akpakun } \\
\text { wlanwlan }\end{array}$ & Bohicon/Dan \\
\hline 25 & LSCn5 & Akpakun vovo & $\begin{array}{l}\text { Savalou/ } \\
\text { Lahotan }\end{array}$ & 69 & GOLn8 & $\begin{array}{l}\text { Akpakun } \\
\text { wéwé cloclo }\end{array}$ & $\begin{array}{l}\text { Glazoué/ } \\
\text { Lifodji }\end{array}$ \\
\hline 26 & KpDCn3 & $\begin{array}{l}\text { Koudrokou } \\
\text { wansanwansan }\end{array}$ & $\begin{array}{l}\text { Djakotomey/ } \\
\text { Kpayahoué }\end{array}$ & 70 & $\operatorname{MSCn} 5$ & $\begin{array}{l}\text { Dansi } \\
\text { suwanro }\end{array}$ & $\begin{array}{l}\text { Savalou/ } \\
\text { Monkpa }\end{array}$ \\
\hline 27 & MSCn1 & Akpakun wéwé & $\begin{array}{l}\text { Savalou/ } \\
\text { Monkpa }\end{array}$ & 71 & MSCn6 & $\begin{array}{l}\text { Akpakun } \\
\text { wéwébamè }\end{array}$ & $\begin{array}{l}\text { Savalou/ } \\
\text { Monkpa }\end{array}$ \\
\hline 28 & AAZn1 & Awadjihèfoun & $\begin{array}{l}\text { Agbangnizou/ } \\
\text { Adanhondjigon }\end{array}$ & 72 & $\mathrm{MSCn} 8$ & $\begin{array}{l}\text { Kpahun } \\
\text { kpalaki balèdji } \\
\text { (balèho) }\end{array}$ & $\begin{array}{l}\text { Savalou/ } \\
\text { Monkpa }\end{array}$ \\
\hline 29 & LAZn1 & $\begin{array}{l}\text { Akpakun } \\
\text { wlanwlan }\end{array}$ & $\begin{array}{l}\text { Agbangnizoun } \\
\text { /Lissazounmè }\end{array}$ & 73 & LSCn2 & $\begin{array}{l}\text { Apakun wéwé } \\
\text { cloclo }\end{array}$ & $\begin{array}{l}\text { Savalou/ } \\
\text { Lahotan }\end{array}$ \\
\hline 30 & LSCn2 & $\begin{array}{l}\text { Akpakun } \\
\text { samandan- } \\
\text { samandan }\end{array}$ & $\begin{array}{l}\text { Savalou/ } \\
\text { Lahotan }\end{array}$ & 74 & $\operatorname{MSCn} 7$ & $\begin{array}{l}\text { Dassiidji } \\
\text { boubidji } \\
\text { tchèdèdji }\end{array}$ & $\begin{array}{l}\text { Savalou/ } \\
\text { Monkpa }\end{array}$ \\
\hline 31 & LSCn1 & $\begin{array}{l}\text { Akpakun } \\
\text { wlinwlinvovo }\end{array}$ & $\begin{array}{l}\text { Savalou/ } \\
\text { Lahotan }\end{array}$ & 75 & LSCn3 & Dansi Ikparè & $\begin{array}{l}\text { Savalou/ } \\
\text { Lahotan }\end{array}$ \\
\hline 32 & $\mathrm{KDCn} 5$ & $\begin{array}{l}\text { Kpahunkundjo } \\
\text { wansanwansan }\end{array}$ & $\begin{array}{l}\text { Djakotomey/ } \\
\text { Kokohoué }\end{array}$ & 76 & HZZZn3 & $\begin{array}{l}\text { Akpakun } \\
\text { wéwé }\end{array}$ & Hlagba-Zakpo \\
\hline 33 & SBZn2 & Akpakun wéwé & $\begin{array}{l}\text { Bohicon/ } \\
\text { Sodohomè }\end{array}$ & 77 & LSCbn5 & $\begin{array}{l}\text { Akpakun } \\
\text { wéwé cloclo }\end{array}$ & $\begin{array}{l}\text { Savalou/ } \\
\text { Lahotan }\end{array}$ \\
\hline 34 & GOLn3 & Akpakun wiwi & $\begin{array}{l}\text { Glazoué/ } \\
\text { Lifodji }\end{array}$ & 78 & GACn2 & $\begin{array}{l}\text { Akpakun } \\
\text { wlanwlan }\end{array}$ & $\begin{array}{l}\text { Glazoué/ } \\
\text { Assanté }\end{array}$ \\
\hline 35 & GOLn2 & Akpakun vovo & $\begin{array}{l}\text { Glazoué/ } \\
\text { Lifodji }\end{array}$ & 79 & GACn3 & Djiyikun & $\begin{array}{l}\text { Glazoué/ } \\
\text { Assanté }\end{array}$ \\
\hline 36 & LBZn1 & Akpakun wéwé & $\begin{array}{l}\text { Bohicon/ } \\
\text { Lissèzoun }\end{array}$ & 80 & AAZn3 & $\begin{array}{l}\text { Akpakun } \\
\text { wéwé } \\
\text { (laiteux) }\end{array}$ & $\begin{array}{l}\text { Agbangnizoun } \\
\text { /Adanhondjigon }\end{array}$ \\
\hline 37 & FOGn2 & Dassiidji daninho & $\begin{array}{l}\text { Glazoué/ } \\
\text { Finangnon }\end{array}$ & 81 & DBZn2 & $\begin{array}{l}\text { Akpakun } \\
\text { wéwé } \\
\text { (laiteux) }\end{array}$ & Bohicon/ Dan \\
\hline 38 & AOGn2 & Kpahunto bodèho & $\begin{array}{l}\text { Ouèssè/ } \\
\text { Gbémè }\end{array}$ & 82 & DBZn3 & Akpakunvovo & Bohicon/ Dan \\
\hline 39 & K1DCn5 & Kpahunkundjo & $\begin{array}{l}\text { Djakotomey/ } \\
\text { Kinkinhoué }\end{array}$ & 83 & GOLn6 & $\begin{array}{l}\text { Akpakunvèdjè } \\
\text { vèdjè }\end{array}$ & $\begin{array}{l}\text { Glazoué/ } \\
\text { Lifodji }\end{array}$ \\
\hline 40 & K1DCn3 & Eglin-jin & $\begin{array}{l}\text { Djakotomey/ } \\
\text { Kinkinhoué }\end{array}$ & 84 & GOLn1 & Akpakun vovo & $\begin{array}{l}\text { Glazoué/ } \\
\text { Lifodji }\end{array}$ \\
\hline 41 & K1DCn1 & Koudrokou & $\begin{array}{l}\text { Djakotomey/ } \\
\text { Kinkinhoué }\end{array}$ & 85 & OBZn & $\begin{array}{l}\text { Dansi kpika } \\
\text { bagarou }\end{array}$ & Banikoara \\
\hline 42 & K1DCn4 & $\begin{array}{l}\text { Gbodo } \\
\text { kpahunkun-yi }\end{array}$ & $\begin{array}{l}\text { Djakotomey/ } \\
\text { Kinkinhoué }\end{array}$ & 86 & AAZtn1 & $\begin{array}{l}\text { Akpakun } \\
\text { wlanwlan }\end{array}$ & $\begin{array}{l}\text { Agbangnizoun } \\
\text { / Adanhondjigon }\end{array}$ \\
\hline
\end{tabular}




\begin{tabular}{|l|l|l|l|l|l|l|l|}
\hline 43 & K1DCn7 & $\begin{array}{l}\text { Kpahunkundjo } \\
\text { wansanwansan }\end{array}$ & $\begin{array}{l}\text { Djakotomey/ } \\
\text { Kinkinhoué }\end{array}$ & 87 & GOLn3 & $\begin{array}{l}\text { Akpakun } \\
\text { wéwé (Blanc } \\
\text { laiteux gros) }\end{array}$ & $\begin{array}{l}\text { Glazoué/ } \\
\text { Lifodji }\end{array}$ \\
\hline 44 & K1DCn2 & $\begin{array}{l}\text { Koudrokou } \\
\text { wansanwansan }\end{array}$ & $\begin{array}{l}\text { Djakotomey/ } \\
\text { Kinkinhoué }\end{array}$ & 88 & LSCbn2 & $\begin{array}{l}\text { Akpakun } \\
\text { wéwé }\end{array}$ & $\begin{array}{l}\text { Savalou/ } \\
\text { Lahotan }\end{array}$ \\
\hline
\end{tabular}

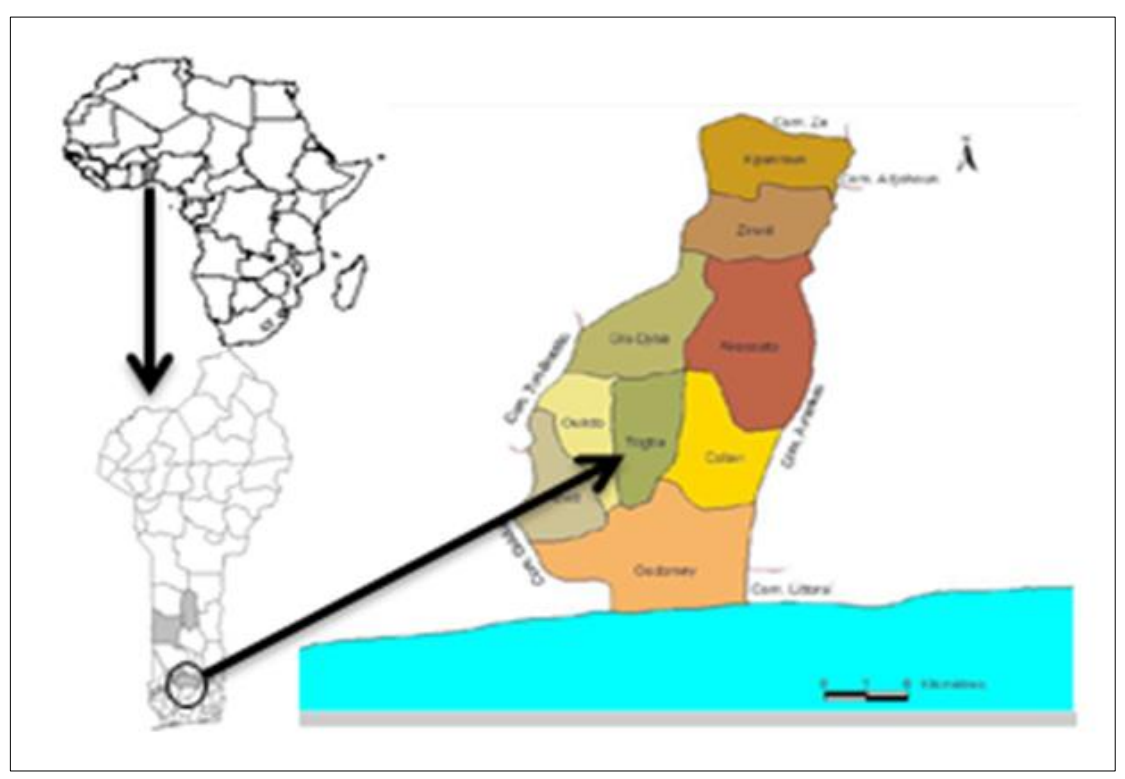

Figure 1 Geographical position of survey zone

\subsection{Experimental design}

The experimental design used was completely randomised with three replications [32]. It consists of 3 randomised complete blocks comprising each one 3 pieces of which each one comprises 33 cultivars. Each elementary piece measures $16.5 \mathrm{~m}$ out of $2.4 \mathrm{~m}$. The pieces are laid out randomly. The spacing between the lines is $0.5 \mathrm{~m}$ and that between sowings is $0.4 \mathrm{~m}$. Some intervals of $0.75 \mathrm{~m}$ and $1 \mathrm{~m}$ isolate two pieces respectively from the same block and the blocks.

\subsection{Methodology of data collection}

On the whole, 23 characters were measured including 12 quantitative characters and 11 qualitative characters (Table 3 ). Measurements were carried out according to the recommendations registered in the descriptor of International Board for Plant Genetic Resources [33]. These observations were made according to the various stages of development of the seedlings.

\subsection{Qualitative characters and codes}

The type of germination (TYG) was determined through the appearance of the cotyledons at the ground surface. Shape of first leaves (FPF), Shape of leaflets (FFE), Chlorophyllous color of leaves (CCF), Way of growth (HCR), Color of first leaves (CPP) and Port color of plants were observed according to the variants of these characters registered in the IBPGR descriptor in 1982 during the different stages of vegetative development of the accessions. Concerning the Color of flower (CFL), Color of integument (COT) Color of the hilum (COH) Shape of seeds (FOG); these parameters were registered respectively three days after the flowering and after the harvest of the seeds.

\subsection{Quantitative characters and codes}

The Duration of germination (TEG) was registered when the cotyledons emerged at the ground surface. Likewise, the Duration of stay of cotyledons (TSC) and appearance of gimlets (TAV) were registered respectively, the days where each accession shed one's cotyledons or the gimlets appeared on each plant. The quantitative parameters such as the Length of the leaflets (LOF), the Width of leaflets (LAF), the Length of petioles (LOP), the Length of the pods (LOG) and Width of pods (LAG) were measured with the graduated ruler on average of 10 plants. Period of flowering (TAF) and Period of appearance of pods (TAG) were recorded respectively since the appearance of the first flowers (the first pods) on 
each plant. Seeds per pod (NGG) was registered on average of 10 pods for each accession selected at random. Regarding 100 seeds weight (P100G), an exactness balance was used.

\subsection{Data analysis}

The data were analyzed by the descriptive statistics (average, frequency, percentage, etc.) and the results are presented in the form of tables and of figures. An analysis of variance was carried out with so as to ascertain if significant differences exist between the cultivars for the studied characters. Moreover, it was carried out multivariate analyses. Thus the matrix of correlation and the Analysis Factorial Correspondences (FCA) were carried out to study the relations between the characters. For the Analysis Factorial Correspondences, the qualitative data were transformed into classes. The Hierarchical Ascendant Classification (CAH) made it possible to set up groups which were characterized by the Discriminating Factorial Analysis (AFD). Data were analyzed using XLSTAT software.

\section{Results and discussion}

\subsection{Qualitative characters and inter-cultivars variability}

From the morphological point of view, the studied accessions have an inter-cultivars variability for the measured qualitative characters. Thus, for the character chlorophyllous color of leaflets (CCF), cultivars presented individuals with green-pale leaflets (45.57\%), other cultivars with leaflets medium-green (26.21\%) and individuals with dark-green leaflets (28.22\%). Regarding the character flowers color (CFL), it was noted more than 54\% individuals were mauve flowers. Individuals with white (23\%), purple (10.08\%) flowers and individuals with white-purple flower (12.90\%) were also noted. For the other qualitative characters such as the shape of leaflets (FFE) more than $93 \%$ of the cultivars presented triangular leaflets; $3.61 \%$ of the cultivars with simple leaflets and $3.21 \%$ of the individuals are with subglobular leaflets. For the way of growth character (HCR), the majority of the cultivars (96.77\%) presented an unspecified way of growth. Only $3.23 \%$ of the individuals presented a pseudo-given growth. The standard character of germination (type of germination, TYG) presented two variables: Epigean (87.09\%) and Hypogean (12.91\%). The port of certain plants was pigmented of anthocyanins (colouring violet) and account for $19.92 \%$ of the characterized individuals whereas other stems of beans present green colourings $(9.35 \%)$ or green-pale $(70.73 \%)$. The greatest number of phenotypical variables was obtained for the integument color (COT) and hilum color (COH) characters. Concerning the COT, studied cultivars presented seeds at one-coloured integument with five variations of which the white (31.11\%), the red (18.6\%), the pink (10.91\%), the milky white (2\%) but equally the black color. Others cultivars presented for the same character, some individuals with two-tone seeds of which approximately $20.75 \%$ are with mottled white integument of red or black, 3.7\% with mottled pink integument of red or of black then finally 1,4\% of the individuals characterized are with mottled red seeds of white. For character $\mathrm{COH}$, seven (07) variables were observed. The seeds of the studied cultivars presented hilums at single colouring of which the white (19.8\%), the light grey $(7.21 \%)$ and the milky white (43.4\%) but, also of the individuals with hilums unicoloured of which the periphery is surrounded by another color. It is the case for example of seeds with white hilum surrounded by black (9.8\%), of grey (8.62\%), red $(8.07 \%)$ or carmine-red (3.1\%) noted in this study. In addition, for the color of the first leaves (CPF) and seeds shapes (FOG), the studied cultivars presented respectively green-pale colourings $(89.3 \%)$, medium-green (6.8\%) and purple $(3.9 \%)$ as of the appearance at the stage of two leaves while the seeds presented three shapes : kidney-shape (33.2\%), round $(11.6 \%)$, and ovals $(55.2 \%)$ after harvest. (Table 2$)$.

\subsection{Repetition effect and descriptive statistics for the quantitative characters}

The descriptive statistics applied to the quantitative variables collected are consigned in Table 3. Significant variations were observed between the average, the minima and the maxima, the standard deviation and the coefficient of variation for the measured characters. Indeed, the evaluated cultivars presented an average value of 6.867 days with a minimum of 5 days and a maximum of 9 days for the time of germination. For the stay time of the cotyledons, it was observed an average of 10.891 days with a minimum of 0 day and a maximum of 23 days. As regards to the time appearance of the gimlets, the cultivars gave an average value of 25.885 days with a minimum of 0 day and a maximum of 35 days. The length of the leaflets, width of the leaflets and length of the petioles showed an average of $8.757 \mathrm{~cm} ; 5.454 \mathrm{~cm}$ and 9.640 $\mathrm{cm}$, respectively with $4.660 \mathrm{~cm} ; 1.500 \mathrm{~cm}$ and $4.000 \mathrm{~cm}$ of minima and maximum of $18.160 \mathrm{~cm} ; 13.000 \mathrm{~cm}$ and 20.000 , respectively. For other characters measured at flowering and fructification stages such as the time of appearance of the floral buttons and the pods, the averages observed were respectively 70.820 and 87.906 whose minimal values were 42.000 and 57.000 and maximum were 103.000 and 127.000. During the harvest, four characters were evaluated. They were the length and the width of the pods, the number of seeds per pods and the weight of 100 seeds. The average values obtained for these various characters were $10.881 ; 1.407 ; 7.543$ and 53.519 , respectively. 
Table 2 Variability in the qualitative characters of the cultivars

\begin{tabular}{|c|c|c|}
\hline Characters & Variables & Frequency \\
\hline \multirow{2}{*}{ Type of germination (TYG) } & Epigean & $76.07 \%$ \\
\hline & Hypogean & $23.93 \%$ \\
\hline \multirow{2}{*}{ Type of growth (HCR) } & Unspecified & $94.67 \%$ \\
\hline & Pseudo-given & $5.33 \%$ \\
\hline \multirow{3}{*}{ Shape of first leaves (FPF) } & Heart shape & $72.58 \%$ \\
\hline & Lanceolate & $20.56 \%$ \\
\hline & Globular & $6.85 \%$ \\
\hline \multirow{3}{*}{ Chlorophyllous color of leaflets (CCF) } & Green-pale & $45.57 \%$ \\
\hline & Medium-green & $26.21 \%$ \\
\hline & Dark-green & $28.22 \%$ \\
\hline \multirow{4}{*}{ Flowers color (CFL) } & Mauve or lilac & $54.03 \%$ \\
\hline & White & $22.98 \%$ \\
\hline & Purple & $10.08 \%$ \\
\hline & White-purple & $12.90 \%$ \\
\hline \multirow{3}{*}{ Port color of plants (CPP) } & Green-pale & $70.73 \%$ \\
\hline & Purple & $19.92 \%$ \\
\hline & Medium/Dark-green & $9.35 \%$ \\
\hline \multirow{3}{*}{ Shape of leaflets (FFE) } & Trifoliate Triangular & $93.17 \%$ \\
\hline & Trifoliate simple & $3.61 \%$ \\
\hline & Trifoliate sub-globular & $3.21 \%$ \\
\hline \multirow{10}{*}{ Integument color (COT) } & White & $31.11 \%$ \\
\hline & Pink & $10.91 \%$ \\
\hline & Black & $2.00 \%$ \\
\hline & Red & $18.60 \%$ \\
\hline & Milky-white & $11.53 \%$ \\
\hline & White streaked with black & $14.32 \%$ \\
\hline & White streaked with red & $6.43 \%$ \\
\hline & Rose streaked with black & $2.30 \%$ \\
\hline & Rose streaked with red & $1.40 \%$ \\
\hline & Red streaked with white & $1.40 \%$ \\
\hline \multirow{5}{*}{ Hilum color $(\mathrm{COH})$} & White & $19.80 \%$ \\
\hline & Light grey & $7.21 \%$ \\
\hline & Milky-white & $43.40 \%$ \\
\hline & White surrounded by black & $9.80 \%$ \\
\hline & White surrounded by grey & $8.62 \%$ \\
\hline
\end{tabular}




\begin{tabular}{|l|c|c|}
\hline \multirow{4}{*}{ First leaves color (CPF) } & White surrounded by red & $8.07 \%$ \\
\cline { 2 - 3 } & White surrounded by carmine red & $3.10 \%$ \\
\hline \multirow{3}{*}{ Shape of seeds (FOG) } & Green-pale & $89.30 \%$ \\
\cline { 2 - 3 } & Medium-green & $6.80 \%$ \\
\cline { 2 - 3 } & Purple & $3.90 \%$ \\
\hline & Kidney shape & $33.20 \%$ \\
\cline { 2 - 3 } & Medium-green & $11.60 \%$ \\
\cline { 2 - 3 } & Rounded & $55.20 \%$ \\
\hline
\end{tabular}

Table 3 Descriptive analysis

\begin{tabular}{|c|c|c|c|c|c|c|}
\hline $\begin{array}{c}\text { Measured } \\
\text { characters }\end{array}$ & $\begin{array}{c}\text { Number of } \\
\text { Individuals }\end{array}$ & Minimum & Maximum & Average & $\begin{array}{c}\text { Standard } \\
\text { deviation }\end{array}$ & $\begin{array}{c}\text { Coefficient of } \\
\text { variation }\end{array}$ \\
\hline TAF & 256 & 42.000 & 103.000 & 70.820 & 14.930 & 4.743 \\
\hline TAG & 256 & 57.000 & 127.000 & 87.906 & 17.493 & 5.025 \\
\hline LOG & 256 & 5.300 & 34.000 & 10.881 & 5.946 & 1.830 \\
\hline LAG & 256 & 0.600 & 3.900 & 1.407 & 0.540 & 2.606 \\
\hline NGG & 256 & 2.000 & 22.000 & 7.543 & 6.019 & 1.253 \\
\hline LOF & 256 & 4.660 & 18.160 & 8.757 & 1.863 & 4.700 \\
\hline LOP & 256 & 4.000 & 20.000 & 9.640 & 2.878 & 3.350 \\
\hline LAF & 256 & 1.500 & 20.000 & 5.454 & 1.903 & 2.866 \\
\hline TEG & 256 & 5.000 & 9.000 & 6.867 & 0.953 & 7.206 \\
\hline TSC & 256 & 0.000 & 23.000 & 10.891 & 7.178 & 1.517 \\
\hline TAV & 256 & 0.000 & 35.000 & 25.855 & 3.940 & 6.562 \\
\hline P100G & 256 & 21.000 & 358.800 & 53.519 & 44.466 & 1.204 \\
\hline
\end{tabular}

Legend: TAF = Time of appearance of the floral buttons, TAG = Time of appearance of the pods, LOG = Length of the pods, LAG = width of the pods, NGG $=$ Number of seeds per pod, LOF = Length of the leaflets, LAF = Width of the leaflets, $\mathrm{LOP}=$ Length of the petioles, TEG = Time of germination, TSC $=$ stay time of the cotyledons, TAV = Time of appearance of the gimlets and P100G, = Weight of 100 seeds.

\subsection{Relationship between characters}

The two axes of the principal components analysis (PCA) explain respectively $57.49 \%$ and $18.26 \%$, respectively of variability that makes $75.74 \%$ of total variability (Table 4). These first two components are enough to analyze the morphological variability of the cultivars. Axis 1 was associated with the characters length of the leaflets (LOF), width of leaflets (LAF), width of petioles (LOP), width of the pods (LAG) and the 100 seeds weight (P100G) which are opposed to the character time of appearance of gimlets (TAV). Axis 2 was associated with the characters time of germination (TEG), time of flowering (TAF), the length of the pods (LOG) and the time of appearance of the pods (TAG). The stay time of the cotyledons over seedling (TSC), the length (LOG) and width (LAF) of the leaflets were correlated positively with axis 1 whereas the time of germination (TEG), the time of flowering (TFL), the time of appearance of the pods (TAG) and the time of appearance of gimlets (TAV) were negatively correlated with this axis. On axis 2, only the characters time of appearance of the gimlets (TAV) and stay of cotyledons (TSC) were negatively correlated. (Table 4). 


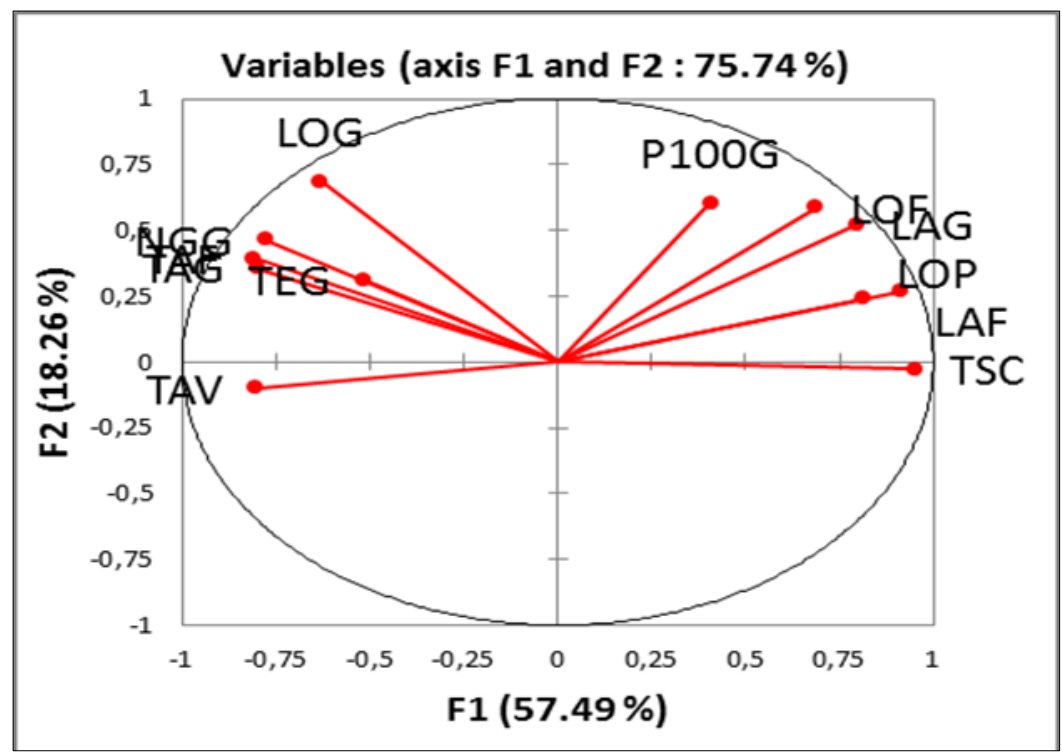

Figure 2 Projection of the characters in the axis system defined by the two first Principal Components

Table 4 Clean vectors and correlations between the variables and the factors (Axis)

\begin{tabular}{|l|c|c|c|}
\hline & Axis 1 & Axis 2 & Axis 3 \\
\hline Clean value & 6.898 & 2.191 & 0.945 \\
\hline \% of the total variability & 57.486 & 18.259 & 7.875 \\
\hline Plurality of the total variability & 57.486 & 75.745 & 83.619 \\
\hline Code characters & Axis 1 & Axis 2 & Axis 3 \\
\hline TAF & -0.810 & 0.393 & 0.266 \\
\hline TAG & -0.801 & 0.358 & 0.297 \\
\hline LOG & -0.633 & 0.686 & -0.241 \\
\hline LAG & 0.797 & 0.522 & 0.144 \\
\hline NGG & -0.780 & 0.465 & -0.352 \\
\hline LOF & 0.688 & 0.588 & -0.260 \\
\hline LOP & 0.815 & 0.241 & -0.232 \\
\hline LAF & 0.911 & 0.268 & -0.070 \\
\hline TEG & -0.518 & 0.313 & -0.242 \\
\hline TSC & 0.953 & -0.026 & 0.104 \\
\hline TAV & -0.802 & -0.100 & 0.158 \\
\hline P100G & 0.406 & 0.604 & 0.603 \\
\hline
\end{tabular}

\subsection{Classification of the cultivars into groups}

The hierarchical ascendant classification (CAH) applied to the different cultivars according to the method of Ward aggregation based on the Euclidean distance gave a structuring of the cultivars studied into three groups (Figure 2). The table 5 gives the distribution of the cultivars in the various groups. 
Table 5 Groups of cultivars

\begin{tabular}{|c|c|l|}
\hline Groups & Number of accessions & \multicolumn{1}{c|}{ Compositions } \\
\hline I & 63 & LSCbn5, ATDn4, MSCn3, GOLn1, KpDCn1, MSCn6, MSCn2, SSCn4, \\
& & ZOGn3, LSCn2, AAZtn1, LSCn5, LSCn3, HDDCn3, SDCn5, HZZZn3, \\
& & PBZn1, LSCbn2, KDCn5, SBZn3, LBZn2, LSCn1, SGCn2, DDCn3, HZZn3, \\
& & SDDCn6, LBZn1, K1DCn3, AAZn3, KDCn2, SBZn2, K1DCn7, KDCn1, \\
& & KBZn1, MSCn5, GOLn8, LAZn1, KDCn6, FOGn1, MSCn7, MSCn8, DBZn3, \\
& & SSCn3, AAZn2, DDCn2, HZZZn2, GOLn6, ZZZn1, AOGn1, SGCn1, MSCn1, \\
& AOGn2, ATDn1, GACn2, DBZn2 \\
\hline II & 3 & OBZn, GOLn3, MaGCn1 \\
\hline III & 22 & SSCn2, HDDCn4, HDDCn1, GOLn4, K1DCn1, GOLn, ATDn2, GACn3, \\
& & K1DCn2, KpDCn2, SSCn1, DDCn1, GACn1, ATDn3, KpDCn4, K1DCn5, \\
& ADTn5, KpDCn3, SDCn3, KDCn4, HDDCn5, FOGCn2 \\
\hline
\end{tabular}

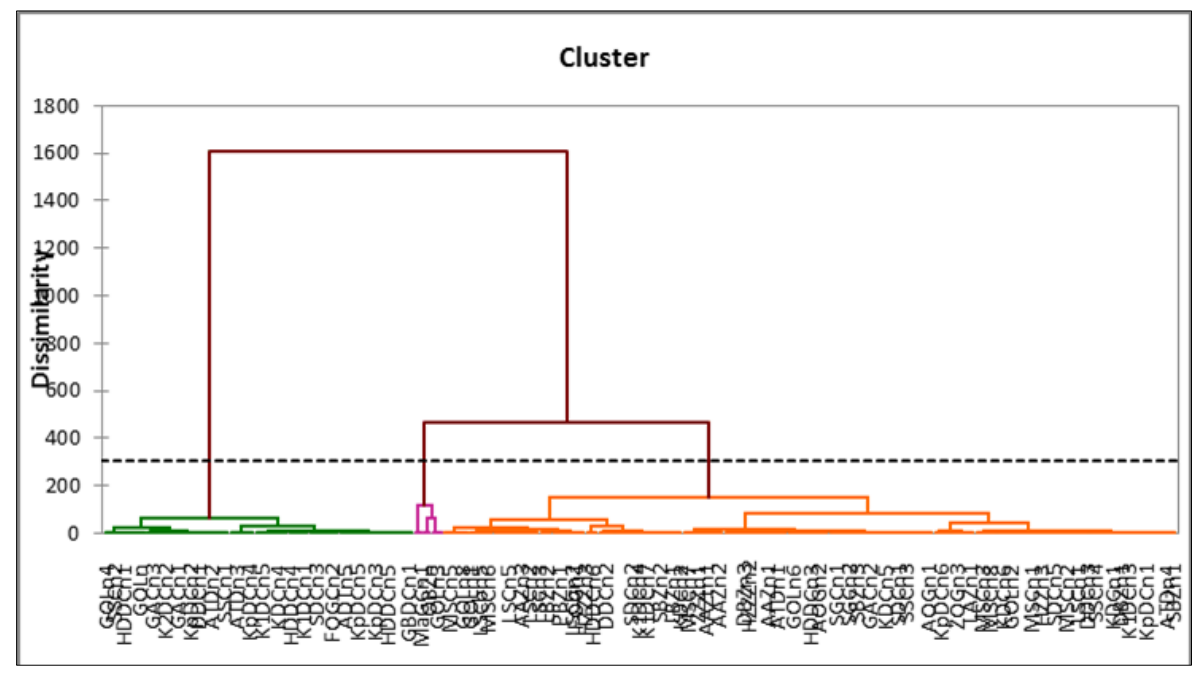

Figure 3 Hierarchical Ascendant Classification

\subsection{Characterization of the different groups}

The Discriminant Factorial Analysis (AFD) made it possible to characterize the three (03) groups resulting from the Hierarchical Ascendant Classification (CAH). Projection in plan 1/2 (75.74\% of total inertia) of different cultivars studied and the quantitative characters made it possible to characterize the three groups resulting from the $\mathrm{CAH}$ (figure 4).

Group I is characterized by cultivars having the length (LOF) and width (LAF) of the leaflets, the length of petioles (LOP), the weight of 100 seeds (P100G) and the stay time of the cotyledons (TSC) relatively average. Among these abovementioned characters, the three characters on which the regrouping of the individuals of group I was based more relate to the length of petioles (LOP), the width of the leaflets (LAF) and the stay time of the cotyledons (TSC).

Group II is represented by cultivars characterized by the length of the pods (LOG), the number of seeds by pods (NGG), times of germination (TEG), appearance of gimlets (TAV), the floral buttons (TAF) and appearance of pods (TAG) relatively high and very close to the maximum values. The characters which contributed more to the discrimination of the individuals of this group are the residence time of cotyledons (TSC), dimensions of the leaflets to knowing LOF and LAF, of the petiole (LOP) but also the weight of 100 seeds (P100G).

Group III consists of cultivars whose times of germination (TEG), flowering (TAF), and appearance of the pods (TAG) are relatively low, but whose weights of 100 seeds (P100G), dimensions of leaflets (LOF and LAF), petiole (LOP) and the pods in particular the width of pods (LAG) gave highest values in the studied collection. 


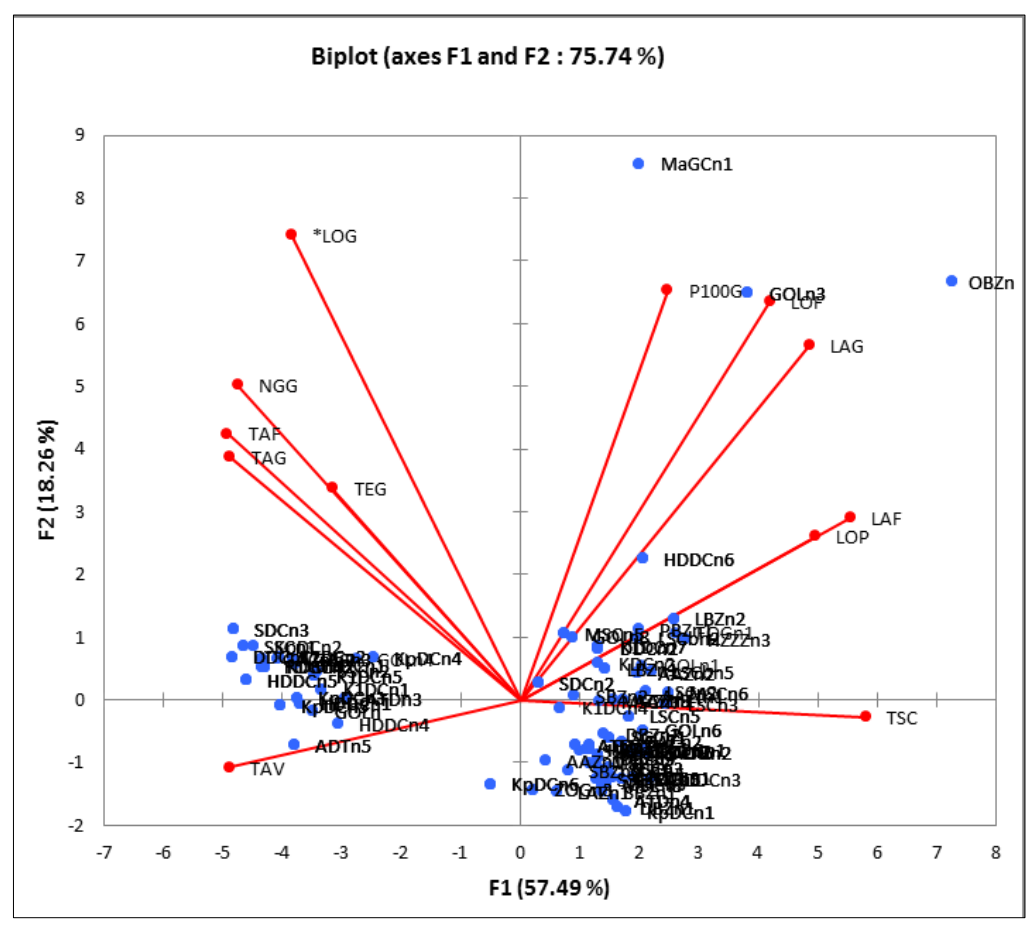

Figure 4 Discriminant Factorial Analysis

\section{Discussion}

The description of morphological variability within a species or inside a genus constitutes a first stage in varietal selection, essential in the knowledge of the genetic resources [34]. Thus, any serious program of genetic improvement exploits necessarily data of morphological variability $[35,36]$. These data allow in the majority of the cases, to direct the improvers in the choice of the objectives of their research [37, 38]. It is in this context that an agro-morphological characterization study of 88 accessions of beans of the Phaseolus genus exploited by the local communities of Benin proved to be necessary for the clarifications of species and made it possible to appreciate the current status of the diversity of beans of the Phaseolus genus on the one hand and to identify the various species of the genus cultivated in Benin on the other hand. The descriptive analysis showed significant differences between the minimal values and the maximum values for the whole of the analyzed morphological characters. This suggested a significant inter-cultivars variability. This strong morphological diversity would result from the farmers' practices of management of the seeds [29]. Indeed, several authors showed that the farmers' practices of management of the seeds, in particular the exchanges of varieties between farmers and associations of cultures in the fields (possible gene flows cause) are at the origin of a significant diversity between the populations of crop plants $[4,29,39,40]$. The study of the qualitative characters such as the type of germination, the shape of the first leaves, the color and the shape of the leaflets, the color of the flowers, the integument and the hilum and seeds shapes confirms this broad variability within the studied collection. Bouchikhi Tani, 2006 [41] had arrived at the same conclusion as for the extreme variability which characterizes beans of the Phaseolus genus. According to the author, beyond the cultivation methods, this significant genetic variability inside this genus would be also justified by the mode of reproduction of the plant which is self-pollination, which make to step in the meiosis process.

In addition, some cultivars presented a hypogean germination. This observation confirms the results of Schmit, 1992; of Baudoin et al., 2002 and from Nyabyenda, 2005 [42, 43, 44] which raised that among the five (05) most cultivated species beans, the species $P$. coccineus presents such a germination. Thus the cultivars of group III which presented hypogean germination in this study would belong to this species.

The strong negative correlations observed between times of appearance of the gimlets, the flowers and the pods on the one hand and the negative correlations between the length of the pods and the number of seeds by pods on the other hand showed dynamic relations between these characters. Similarly, strong positive correlations was observed between the dispatcher of the leaflets and the stay time of the cotyledons on the one hand and positive correlations was also observed between the lengths of the petioles, the leaflets and the pods on the other hand. These strong correlations noted between certain studied characters could be explained by the fact that these characters are genetically dependent on one another i.e. they are probably under the influence of same genes or pleiotropic effect [32, 45]. Consequently, 
during studies aiming at the genetic improvement of beans, the choice of the one of the characters for pleiotropic purpose would indirectly imply the simultaneous study of all the characters which depend on the same gene(s).

For the majority of the studied cultivars, an interval from 15 to 24 days separates time from appearance of the pods to the time of flowering. Then, the interval between flowering and fructification of beans of the phaseolus genus remains generally constant whatever the species or the variety. Thus, the differences in cycles observed at the various species and/or varieties generally relate to the vegetative cycle and the period of filling of the pods to maturation. The cultivars which presented some low values of the standard deviations between certain characters permitted to observe a regrouping of these individuals around the average values. However this situation doesn't mask the existence of a variability between the cultivars in particular for the characters weight of 100 seeds (P100G), time of flowering (TAF) and time of appearance of the pods (TAG). This variability is expressed by relatively large coefficients of variation (4.743 for TAF and 5.025 for TAG). In this study, average values relatively larger were noted for the characters time of flowering and appearance of the pods. These results are not in agreement with those of Okii et al., 2014 [32] and could be explained by the fact that during the test, a hydrous stress has affected the cultivars, which could slow down their vegetative growth and consequently increase the duration of their cycle of development. In the Phaseolus genus, it was reported that the cycle of development of species is conditioned by several factors among which the distribution of the rain in time, physicochemical parameters of the ground (salinity, texture, etc.) and many other climatic factors [46, 47, 48, 49]. Indeed, according to whether the distribution of the rain be discontinuous, the deceleration of the cycle of development of certain late varieties can undergo variations up to approximately 300 days, which confirms the observations of our study. The Hierarchical Ascendant Classification (CAH) grouped the cultivars in three major groups (GI, GII and GIII). The genotypes were discriminated more by the number of seeds per pod, times of survey of the gimlets, flowering, the formation of the pods, but also by dimensions of the leaves in particular the length and the width. Similar conclusion was made in the previous reports on the botanical classification of the species of Phaseolus genus [42, 43]. These authors described the species Phaseolus vulgaris as being a dwarf plant or with raised stems, climbing with average, white flowers or more or less dark lilac whose thimbles are lengthened with parchment or without parchment. The seeds of these plants of extremely variable size, are very flattened, without radiant scratches of which the number can vary from 2 to 12 or more according to the variety. Over the 88 studied cultivars, the individuals of group I confirm the observations of these authors. As for the species Phaseolus lunatus, Denaiffe, 1902 in its work decorated with 272 figures and others researchers for this plant $[50,51]$ describe the species as being some high plants, seldom dwarf, with small or big flowers white whose thimbles are short but broad or very broad. Generally flattened seeds or kidney shape, their number per pod varied from 2 to 4, in the shape of half-circle or crescent, with radiant scratches of the hilum towards the circumference. Group II defined by the CAH presents similar characteristics to those of Denaiffe and would be consequently of this species. This survey which presented an outline of the genetic resources of beans of the Phaseolus genus on the one hand and the genetic variability observed within the collected accessions on the other hand, constitutes a significant asset for work of selection and classification of the species of the Phaseolus genus. That would allow a better exploitation of their genetic resources in culture in the future programmes of selection of Phaseolus spp in Benin, because the preliminary condition for any program of varietal selection remains incontestably the knowledge of the existing germplasm.

\section{Conclusion}

The results of this study which aimed to evaluate genetic diversity and the identification of the species of beans of the Phaseolus genus revealed the existence of a significant diversity inside the studied collection. A wide phenotypical variability was observed among the accessions and they were classified into three groups directly representing species of the genus in study. The tests of correlation indicated a significant correlation between certain morphological characters. The taking into account of the one of these characters in the programs of varietal selection would imply a simultaneous study of the characters genes which carry them. It's the event for example of the characters Length of the pods (LOG) and Number of seeds per pod (NGG). A molecular characterization is necessary within each species to evaluate the genetic diversity of beans and also to clarify synonymies for finally making a rational use of their resources available.

\section{Compliance with ethical standards}

\section{Acknowledgments}

The authors acknowledge all colleagues especially Symphorien Agbahoungba, bosom friends particularly Elias A. Zountchegbe and farmers who participated in the implementation of this study but also, the Prof. Yédomonhan Hounnankpon as for the botanical accuracy. 


\section{Disclosure of conflict of interest}

The authors declare that they have no conflict of interest. This article is one of the results of the first author's research of doctorate thesis.

\section{References}

[1] Romero AO, Damian HMA, Rivera TJA, Baez SA, Huerta LM, Cabrera HE. The Nutritional value of Beans (Phaseolus vulgaris L.) and its importance for Feeding of Rural communities in Puebla-Mexico. International Research Journal of Biological Sciences. 2013; 2(8): 59-65.

[2] Marechal R, Mascherpa J-M, Stainier F. Etude taxonomique d'un groupe complexe d'especes des genres Phaseolus et Vigna (Papilionaceae) sur la base de données morphologique et pollinique, traitees par l'analyse informatique. Boissiera. 1978; 28: 2-7.

[3] Freytag GF, Debouk DG. Taxonomy, distribution, and ecology of the genus Phaseolus (LeguminosaePapilionodeae) in North America, Mexico and Central America. Taxonomía, distribución ecología del género Phaseolus (Leguminosae-Papilionodeae) en Norteamérica, México y Centroamérica. Sida, Botanical Miscellany. $2002 ; 1-23$.

[4] Milognon HW, Missihoun AA, Sedah P, Agbo RI, Assogbadjo AE, Agbangla C. Utilisation des microsatellites chloroplastiques (SSRcp) dans la relation phylogénétique des haricots cultivés du genre Phaseolus au Centre et Sud Bénin, Afrique de l'Ouest. Afrique SCIENCE. 2019; 15(1): 1-11.

[5] Milognon H, Missihoun AA, Agbo RI, Assogbadjo AE, Agbangla C. Connaissances endogènes et contraintes biotiques de production des haricots cultivés du genre Phaseolus au Centre et Sud Bénin, Afrique de l'Ouest. Journal of Applied Biosciences. 2020; 145: 14938-14954.

[6] Debouck DG. Diversity in Phaseolus species in relation to the common bean. In: Common bean improvement in the twenty-first century. Springer Netherlands. 1999; 1: 25-52.

[7] Wortman CS. Céréales et légumes secs Editeurs PROTA1, Wageningen, Pays Bas. 2006.

[8] IRAD. Contribution de la recherche à l'amélioration de la production et la consommation des légumineuses alimentaires au Cameroun, C2D/ Programme d'Appui à la Recherche Agronomique, Projet 6, Légumineuses. 2013; 57.

[9] N'gbesso MF-P, Fondio L, Dibi BEK, Djidji HA, Kouame CN. Etude des composantes du rendement de six variétés améliorées de niébé (Vigna unguiculata L.). Journal of Applied Biosciences. 2013; 63: 4754-4762.

[10] Marilyn LB, Jay KU. A proprietary alpha-amylase inhibitor from white bean (Phaseolus vulgaris): A review of clinical studies on weight loss and glycemic control. Nutrition Journal. 2011; 10(24): 1-10.

[11] Torres M. Légumes et céréales. (Eds.), Delville, Paris. 2004; 104-108.

[12] Lenoir L. Effet protecteur des polyphénols de la verveine odorante dans un modele d'inflammation colique chez le rat. Médecine humaine et pathologie. Thèse de Doctorat de Nutrition. Université d'Auvergne. Science de la vie et de la sante. $2011 ; 176$.

[13] Saada DA, Chabane OA, Bouderoua K, Selselet-Attou G. Place des légumes secs dans l'alimentation humaineAtouts nutritionnels et impact sur la santé. Forum Régional pour le Développement des Légumineuses Alimentaires - Université de Mostaganem 28, 29 et 30 Novembre 2016 ; 1-5.

[14] FAO. Les avantages nutritionnels des légumineuses. 2016.

[15] PABRA. Pabra Narrative Annual Report 2014-2015. Pan-African Research Alliance. 2013; 27.

[16] AAFC. Le Bulletin Bimensuel Agriculture and Agri-Food Canada, le 13 octobre 2000; 13(16): 1-6.

[17] PABRA. Des haricots de meilleure qualité pour l’Afrique. Kampala / Uganda Public Health. $2006 ; 1$.

[18] Guenguen J et Lemarie J. Composition, structure, et propriétés physicochimiques de Légumineuses et d'oléagineux. In, GODON B. Les proteines vegetales. Lavoisier Tec et Doc. Paris. 1996; 666.

[19] Calet C. Les Légumineuses sèches: Apport protidique. Cah. Nut. Diet. 1992; 27(2): 99- 108. 
[20] Andriamamonjy N. Valeur nutritionnelle de graines sèches de 7 variétés de haricot commun (Phaseolus vulgaris) et de 2 variétés d'ambérique (Vigna umbellatta). Mémoire de DEA en Biochimie Appliquée aux Sciences de l'Alimentation et de la Nutrition. Université d'Antananarivo (Madagascar). 2000; 76.

[21] FAO. Les graines de légumineuses dans l'alimentation humaine. FAO-Alimentation et nutrition 20- Rome. 1982; 152.

[22] Boyeldieu J. Produire des grains oléagineux et protéagineux. Lavoisier. Tec et Doc.- Paris. 1991; 234.

[23] Cuq JL and Leynaud-Rouaud C. Les graines de légumineuse. In, Dupin H, Cuq JL, Malewiak M I, Leynaud-Rouaud C. Alimentation et nutrition humaine. ESF. Paris. 1992 ; 941-961.

[24] Champ MA, Magrini MB, Simon N, Le Guillou C. Les légumineuses pour l'alimentation humaine: apports nutritionnels et effets santé, usages et perspectives. In : Schneider A and Huyghe C. Les legumineuses pour des systemes agricoles et alimentaires durables. Editions Quae. 2002; 615.

[25] Akande SR, Balogoun MO. Evaluation and heritability studies of local Lima bean (Phaseolus lunatus L.) cultivars from south-west Nigeria, Revista UDO Agrícola. 2007; 7(1): 22 - 28.

[26] Broughton WJ, Hernandez G, Blair MW, Beebe S, Gepts P, Vanderleyden J. Beans (Phaseolus spp.) - Model Food Legumes. Plant and Soil. 2003; 252(1): 55-128.

[27] Minagri. Programme National de Sécurité Alimentaire. Version amendée après l'atelier national du 16 Décembre $2010 ; 5$.

[28] Aly D, Dah-Dovonon ZJ, Dansi A. Deuxième rapport sur l'état des ressources phytogénétiques pour l'alimentation et l'agriculture au Bénin. Ministère de l'Agriculture de l'Elevage et de la Pêche. 2007; 59.

[29] Milognon HW. Caractérisations ethnobotanique, agromorphologique et étude phylogénétique des haricots du genre Phaseolus dans le Sud et Centre Bénin. Mémoire de fin de formation de Master, Université d'AbomeyCalavi (Bénin). 2017; 82.

[30] MEPN. Convention cadre des Nation Unies sur le changement climatique. Programme d'action National d'adaptation aux changements climatiques du Bénin (PANA-BENIN). 2008; 123.

[31] Dagba AR, Missihoun AA, Adoukonou-Sagbadja H, Savi MK, Ahanhanzo C, Agbangla C. Agromorphological variability of pearl millet (Pennisetum glaucum (L.) R. Br.) cultivars grown in Bénin. Journal of Experimental Biology and Agricultural Sciences. 2015; 3(1): 395- 406.

[32] Okii D, Tukamuhabwa P, Kami J, Odong T, Namayanja A, Mukabaranga J, Paparu P, Gepts P. Morphological diversity of tropical common bean germoplasm. African Crop Science Journal. 2014; 22(1): 59-67.

[33] AGPG: International Board for Plant Genetic Resources (IBPGR), Phaseolus vulgaris descriptor list. Secretariat, Rome, Italy. 1982.

[34] Radhouane L. Etude de la variabilité morpho-phénologique chez Pennisetum glaucum (L.) R. Br. Plant Genetic Resources Newsletter. 2004; 138:18-22.

[35] Smith SE, Doss AA and Warburton M. Morphological and agronomic variation in North African and Arabian alfalfas. Crop Science. 1991; 31: 1159- 1163.

[36] Missihoun AA, Adoukonou-Sagbadja H, Ezin V, Sedah P, Dagba RA, Ahanhanzo C, Agbangla C. Phenotypic variability and racial classification of landraces of sorghum (Sorghum bicolor (L.) Moench) collected in the Northwestern Benin. International Journal of Agronomy and Agricultural Research. 2015; 7(4): 23-35.

[37] Fraleigh B. Importance des banques de ressources phytogénétiques In: Amélioration et protection des plantes vivrières tropicales, (Eds) Saint Pierre C-A, Demaly Y, AUPELF-UREF, Québec, Canada. 1987; 13-18.

[38] Hamissou Z, Ibrahim AA, Seyni B, and Hamissou AM. Caractérisation agromorphologique des accessions de sésame (Sesamum indicum L.) collectées au Niger. International Journal of Innovation and Applied Studies. 2020; 29(4): 902-914.

[39] Mckeye D, Emperaie L, Elias M, Pinton F, Robert T, Desmoulière S, Rival L. Gestion locales et dynamiques régionales de la diversité variétale du manioc en Amozonie. Genetic Selection Evolution. 2001; 33: 465-490.

[40] Delaunay S, Tescar R-P, Oualbego A, Vom-Brocke K, Lançon J. La culture du coton ne bouleverse pas les échanges traditionnels de semences de sorgho. Cahiers Agricultures. 2008; 17: 189- 194. 
[41] Bouchikhi T. Bioefticacité de la substance des feuilles de deux variétés de haricot Phaseolus vulgaris sur les différents états et stades de développement de la bruche du haricot Acanthoscelides obtectus, (Coleoptera, Bruchidae). Université Aboul Bêkaïd Tlemcen. 2006; 1-103.

[42] Schmit V. Etude de Phaseolus polyanthus Greenm. et autres taxons du complexe Phaseolus coccineus L. Thèse de doctorat, Faculté Universitaires des Sciences Agronomiques de Gembloux. 1992; 198.

[43] Baudoin JP, Demol J, Louant BP, Maréchal R, Mergeai G, Otoul E. Amélioration des plantes : application aux principales espèces cultivées en régions tropicales. Gembloux: Presses Agronomiques de Gembloux. 2002; 23.

[44] Nyabyenda P. Les plantes cultivées en régions tropicales d'altitude d'Afrique: Généralités, Légumineuses alimentaires, Plantes à racines et tubercules et Céréales. Gembloux : Presses Agronomiques de Gembloux Bruxelles. 2005; 225.

[45] Miko I. Genetic dominance: genotypephenotype relationships. Nature Education. 2008; 1: 1- 12.

[46] Sharma KK, Lavanya M. Recent developments in transgenics for abiotic stress in legumes of the semi-arid tropics. JIRCAS Working Report. 2002; 23: 61-73.

[47] Bayuelo-Jiménez JS, Debouck DG, Lynch JP. Growth, gas exchange, water relations, and ion composition of Phaseolus species grown under saline conditions. Field Crop Resistance. 2003; 80(3): 207-222.

[48] Rainey KM, Griffiths PD. Inheritance of heat tolerance during reproductive development in snap bean (Phaseolus vulgaris L.). Journal of American Society, Horticulture and Science. 2005; 130: 700-706.

[49] Mainassara ZA, Bouaziz S, Boulbara LT, Mohamed HEA. Paramètres agronomiques liés à la tolérance au sel chez le haricot (Phaseolus vulgaris L.), Biotechnology Agronomy Society and Environment. 2008; 13(1): 113-119.

[50] Kaplan L, Lynch TF. Phaseolus (Fabaceae) in archaeology: AMS radiocarbon dates and their significance for precolombian agriculture. Economy Botanical. 1999; 53: 261-272.

[51] Serrano-Serrano ML, Andueza-Noh RH, Martinez-Castillo J, Debouck DG, Chacon Sanchez MI. Evolution and domestication of Lima bean in Mexico: Evidence from ribosomal DNA. Crop Science. 2012; (52)4: 1698-1712. 